\section{EMBRYAIDDLE \\ Aeronautical University}

SCHOLARLY COMMONS
International Journal of Aviation, Aeronautics, and Aerospace

\title{
Aircraft Interior Design And Satisfaction For Different Activities; A New Approach Toward Understanding Passenger Experience
}

\author{
Golnoosh Torkashvand \\ Florida Institute of Technology - Melbourne, gtorkashvand2014@my.fit.edu \\ Lucas Stephane \\ Florida institute of technology Melbourne, Istephane@fit.edu \\ Peter Vink \\ Delft University of Technology, p.vink@tudelft.nl
}

Follow this and additional works at: https://commons.erau.edu/ijaaa

Part of the Arts and Humanities Commons, Aviation Commons, Operations Research, Systems Engineering and Industrial Engineering Commons, Social and Behavioral Sciences Commons, and the Technology and Innovation Commons

\section{Scholarly Commons Citation}

Torkashvand, G., Stephane, L., \& Vink, P. (2019). Aircraft Interior Design And Satisfaction For Different Activities; A New Approach Toward Understanding Passenger Experience. International Journal of Aviation, Aeronautics, and Aerospace, 6(2). https://doi.org/10.15394/ijaaa.2019.1290

This Article is brought to you for free and open access by the Journals at Scholarly Commons. It has been accepted for inclusion in International Journal of Aviation, Aeronautics, and Aerospace by an authorized administrator of Scholarly Commons. For more information, please contact commons@erau.edu. 


\section{Aircraft Interior Design And Satisfaction For Different Activities; A New Approach Toward Understanding Passenger Experience}

\section{Cover Page Footnote}

I would like to express my very special thanks to professor Peter Vink who helped me a lot with the paper. His great advice on how to better perform the research was so valuable. I would also like to appreciate Dr. Lucas Stephane for the continuous support of my Ph.D study as well as the current paper which is part of that research, for his patience, motivation, and immense knowledge. 


\section{Introduction}

The attention for passenger experience in air travel is growing (De Lille, Santema, Bouwens, Schultheis, \& Vink, 2016). This is also shown in the increasing number of experts visiting the Passenger Experience conferences and trade fairs such as the Passenger Terminal Expo, Future Travel Experience, and the IATA World Passenger Symposium. Despite the industry focus and attention for airport passenger experience, very little is actually known about passenger needs in flight (Harrison, Popovic, Kraal, \& Kleinschmidt, 2012; Popovic, Kraal, \& Kirk, 2010). It is important to understand these needs since they are an important role in airline profitability. Airlines can, in principle, increase their profit margins by reducing maintenance costs. However, according to Brauer (2004), at a typical airline, a 14\% reduction in maintenance costs will result in only a $1 \%$ improvement in the airline's profit margin, while a passenger revenue increase of only $1 \%$ has approximately the same result.

This study is part of an overall human-centered design thinking research spanning all stages, i.e. need-finding, ideation, prototyping, and evaluation (Meinel, Leifer, \& Plattner, 2011). Part of the need-finding stage, this study presents the results of several retrospective interviews and brainstorming sessions, as well as the results of the survey described in this paper.

To increase passenger satisfaction and also revenue, it is useful to understand the flight selection behavior of passengers. According to Brauer (2004), most passengers first select the most convenient route and departure time at the best price. In those cases, in which the passenger is indifferent between equally convenient flights at a similar price, other factors can have an important role. These other aspects include comfort, service, airline reputation for on-time performance, and marketing programs such as frequent flyer programs (Vink \& Brauer, 2011). It is therefore useful to study the role played by these factors and understand their importance. It is also useful to study what factors really contribute to passenger satisfaction. Many studies have been performed in this field (e.g. Blok et al., 2007; Bonilla; Chen, 2008; Koniezcny, 2001; López-Bonilla \& López-Bonilla, 2008; Vink et al., 2012), showing for instance that for short distances, on-time performance is more important and for long-haul flights, comfort and service aspects play a more important role. Several studies also show that before redesigning the interior or inflight services, it is useful to elicit passengers' knowledge on their experience related to various inflight activities (Hiemstra-van Mastrigt 2015; Smulders et al., 2016).

Under the foregoing flight selection paradigm, it is interesting to know more about what satisfies individual passengers and what influences their choice to pay more for flight fares. While it is less common than the schedule and price driven paradigm described above, it could be true that some passengers do, in fact, choose a slightly more convenient flight with a slightly higher fare. On the other hand, in order to design for more satisfaction in a majority of passengers, as well as not to sacrifice revenue and business aspects, one solution could be to do product differentiation. Product differentiation is 
also a possible way for airlines to gain a competitive advantage over other airlines (Alderighi et.al, 2012). Product differentiation and product positioning however are not possible unless we gain ample knowledge of what satisfies each passenger during flying.

This study is performed for gaining additional insights about cabin configurations and services that satisfy passengers. Smulders et al. (2016) and Lille et al. (2016) showed that the satisfaction is also influenced by what passengers tend to do, meaning that different activities ask for different environments. Therefore, in this study the satisfaction is not studied in general but based on the activity's passengers perform inflight.

The research question of this paper is: what influences aircraft interior satisfaction while performing different activities? Gathering this knowledge is mandatory in order to increase overall flight satisfaction by focusing on experiences passengers perceive from each activity in the flight context.

\section{Method}

The study started with retrospective interviews and brainstorming sessions. More than 10 graduate students and professors of the Human-Cantered Design graduate program, Florida Institute of Technology were asked to recall and brainstorm on all their inflight activities. A total of 23 activities were elicited from these interviews and brainstorming sessions.

To study satisfaction rate from performing these activities, as well as the importance of these activities in flight situations, a 26-question survey was designed and setup online, with a total of 93 respondents. There was no limitation for the respondents' demography. The only requirement for the survey was that the respondents had flown at least one long haul flight, i.e. more than 6 hours. Diversity of demographics was taken into account. Out of the 93 respondents, $53.3 \%$ were male and $46.7 \%$ female. Also, different age groups took part in the study ranging from 20 years old to 83 years old.

Respondents were asked to rate their perception of "how important" different activities during flying were to them. In the next question they were also asked to rate "how satisfied" they were while performing those inflight activities. The answers for both questions ranged from 1 to 5 which in the first question was equivalent to "not at all important" to "extremely important" and for the latter one from "not at all satisfied" to "extremely satisfied." The question on satisfaction also allowed for open comments so passengers could explain their ratings.

In the second part of the survey, participants were asked to choose if they usually travel alone or as couples or groups of family or friends. They were also asked to write the total number of travelers including children aged 6 and under. These questions were designed for gaining knowledge on how travelling individually or as couples or groups of friends and families with very young children affects their behavior of choosing specific seats in various cabin configuration. This knowledge also helps us to understand if travelling either 
individually or as couples or groups influences passengers' perceptions of important activities and the degree of satisfaction associated to those activities.

To learn about passengers' seat preferences, five of the most common aircraft seat row configurations for long haul flights were selected and presented to respondents (Figure 1). Participants were asked to choose their seat preference in each configuration based on the total number of travelers they specified previously. The answers to this question may validate how different seat arrangements affect passengers' seat choice, i.e. window seat, aisle seat, or middle seat.

\section{$\wedge^{\wedge}$ Front of the aircraft ${ }^{\wedge}$}

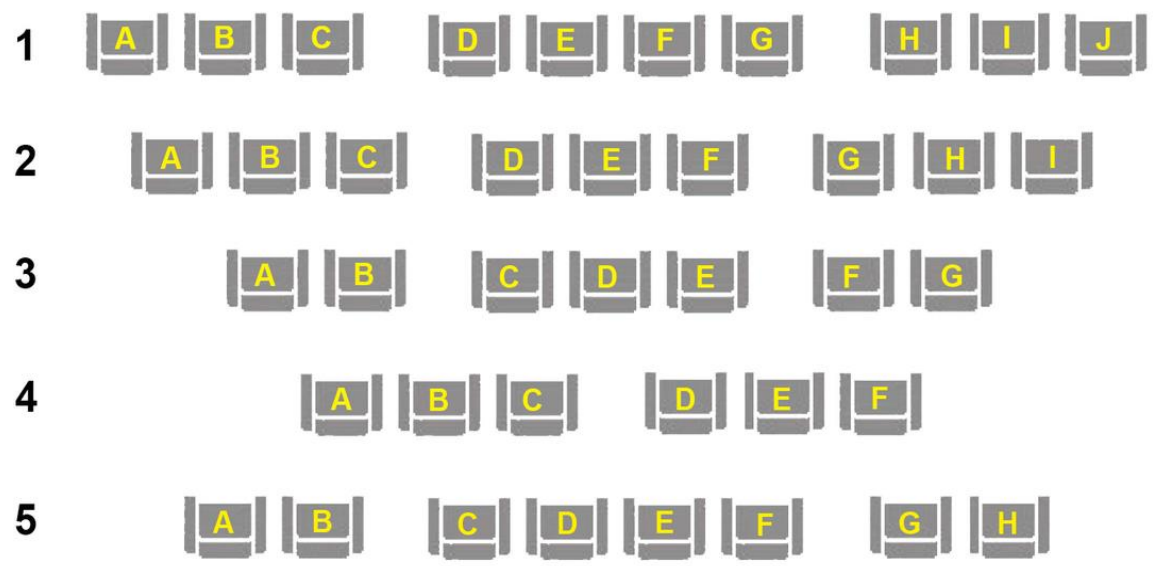

Figure 1: Five Most Popular Seat Configuration for Long-Haul Flights.

\section{Statistical Analysis}

To compare if there is a significant difference between individual, couple, and group travelers' perceptions of the importance of their activities during flying, analysis of variance (ANOVA) and Tukey's multiple comparison tests were conducted. First, ANOVA tests if the zero hypothesis is rejected or not. Tukey's post-hypothesis test enables to learn which types of travelers differ from the rest.

The same procedure was also performed for the same groups of travelers on their perceptions and their satisfaction rate for the identified activities. An additional analysis was performed in order to investigate if there are any significant differences in the perception of importance by activity, as well as the satisfaction rate by those activities for traveler groups that include at least one child under age of 6 with the rest of travelers.

A similar analysis was performed to check if there are any differences between factors affecting flight choices of individual, couple and group travelers. A frequency analysis was also performed to understand which seats in each configuration are the most popular for each type of individual, couple and group travelers, as well as for the overall sample of respondents. 


\section{Results}

\section{Activity Frequency and Satisfaction}

More than $45 \%$ of participants mentioned that they travel alone; $35 \%$ mentioned they travel with one other person, while $20 \%$ travel in groups of 3 travelers or more, some including children less than 6 years old.

The most important activities mentioned by the participants were 'resting/relaxing' (4.27/5) followed by 'using the bathroom' (4.17/5) and 'sleeping' (4.0/5). The least important included 'talking to neighbors' (2.1/5) and 'talking to other group mates' $(2.62 / 5)$, and 'playing/working with cell phones' (2.98/5) (Figure 2). Satisfaction rate was also the highest among activities such as 'watching in-flight movies' (3.58/5),'thinking and observing' $(3.45 / 5)$ as well as 'checking real time flight status' (3.45/5). The lowest satisfaction was found for the activities 'sleeping' (2.75/5) and 'in-/egress of the seat' (2.79/5) (Figure 3).

The results of variance analysis and multiple comparison tests show that there is no significant difference in the mean ratings of different activities among the three groups of passengers (see Tables $1 \& 2$ ). The pairwise comparison showed that they are equal regarding their $p$ value. This means that the same activities are often mentioned while travelling individually, in couples or in larger groups.

Regarding the satisfaction rate, two activities were significantly different in different groups of travelers (Table 2). For 'Taking care of the family' $(\mathrm{P}=0.0020)$, individual and couple travelers were similar $(\mathrm{P}$ adj $1=0$. 9980223, $\mathrm{P}$ adj2 $=0.0028274)$ while group travelers ( $>3$ persons) were significantly different $(\mathrm{P}$ adj3 $=0.0044313)$ from both groups of individual and couple travelers. Also, for 'interacting with flight attendants' $(\mathrm{P}=0.0074)$, individual and couple travelers showed a similar satisfaction rate $(P$ adj $1=0$. 7786308, $P$ adj2 =0. 0059937), while group travelers were significantly different $(\mathrm{P} \operatorname{adj} 3=0.0329119)$ from individual and couple groups.

\section{Seat Choice}

Frequency analysis regarding the relationships between traveler type and seat choice showed that individual travelers have similar preferences on choosing between window and aisle seat. They show very little interest in middle seats and middle abreast seats (figure 4-8). Couple travelers also prefer the window and aisle seats. However, in arrangements with three seats, they are willing to choose a middle seat for the second person as well. In addition, couple travelers barely choose any middle seat option (Figures 9-13). For group travelers, their main criteria for choosing seats are that they could sit next to each other without an aisle in between. If their number does fit the seats on the window sides, they choose window over middle rows. 


\section{Differences Between Individual, Couple, and Group Travelers on Flight Choices}

Regarding factors that affect flight choices, there was no significant difference between ticket price, airline image, and inflight services between the individual, couple and group travelers (Table 1). Only the 'schedule of timetable' and 'seat comfort' were significantly different in the couple travelers, while individual and group travelers had a similar attitude.

Also, no significant differences were found between two categories of travelers who travel with children under 6 with the other travelers related to their perception of importance and satisfaction by activities.

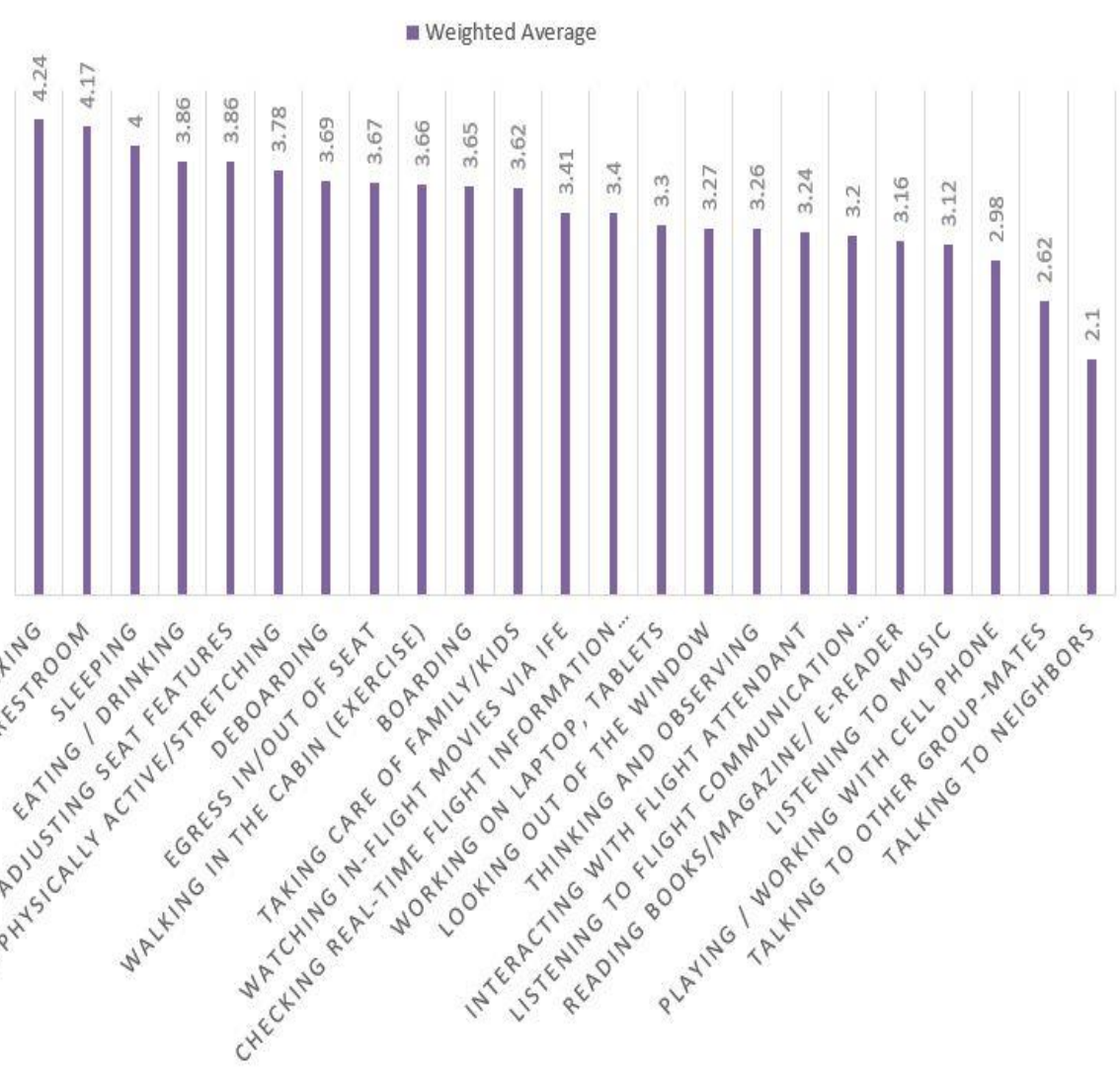

Figure 2. Overall average of important activities. 


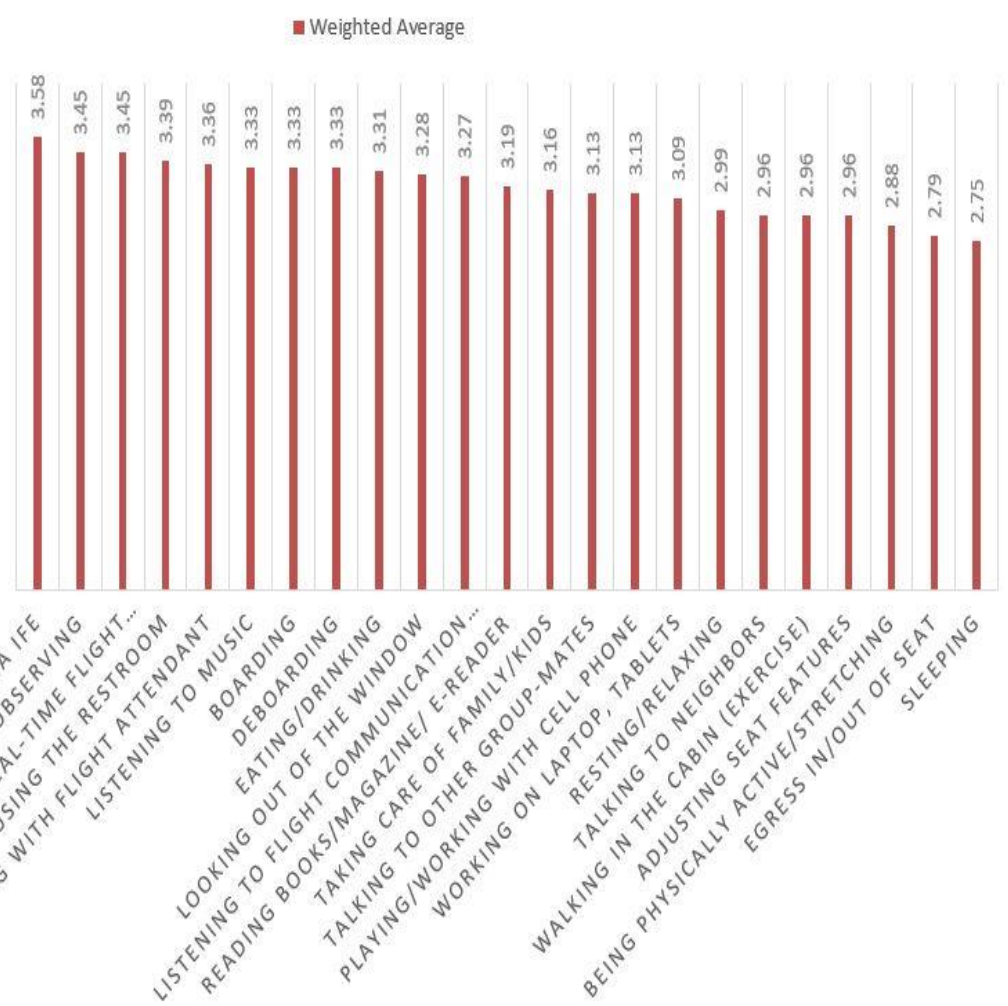

Figure 3. Overall Average Satisfaction by Activities.

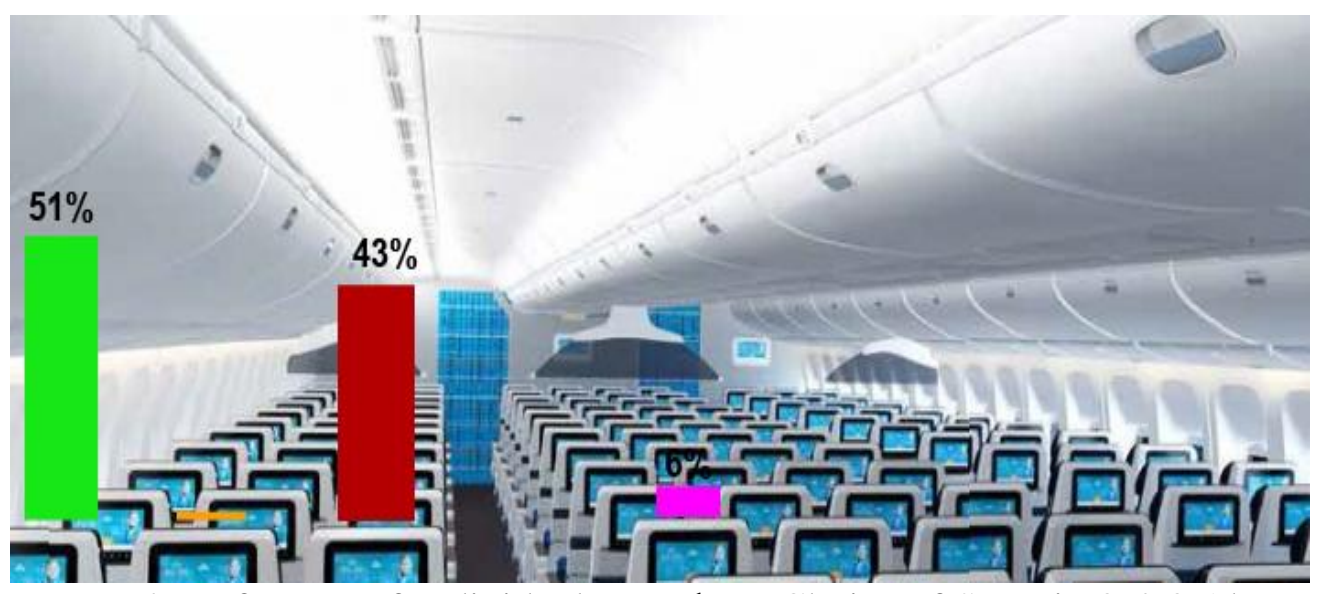

Figure 4. Preference of Individual Travelers' Choice of Seats in 3-4-3 Abreast Cabins Such as Boeing 777. 


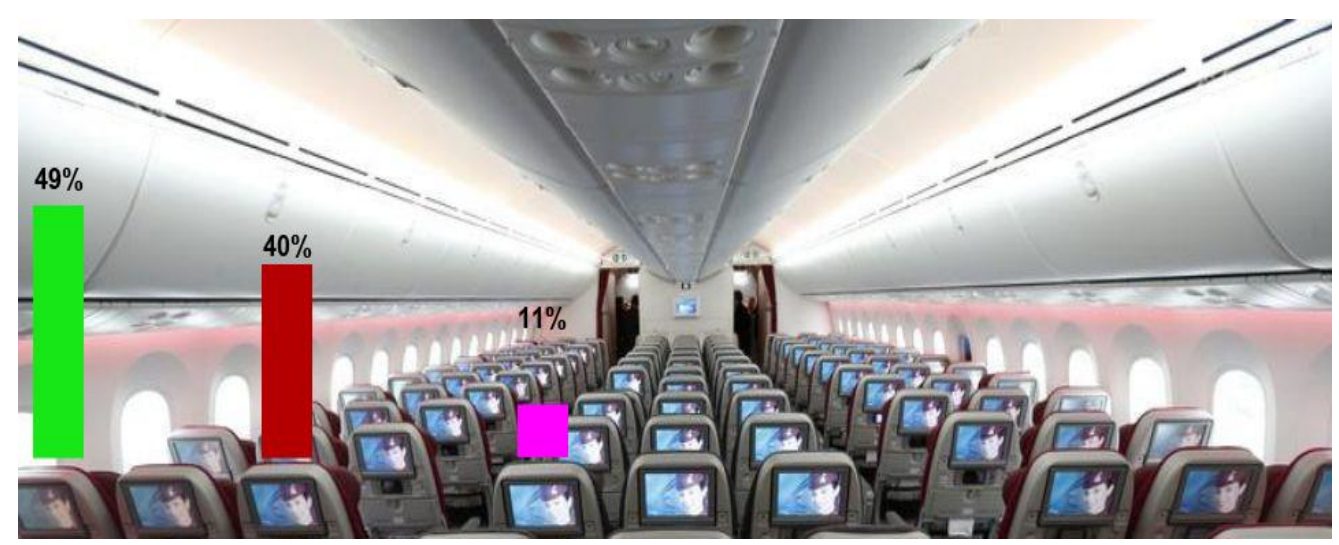

Figure 5. Preference of Individual Travelers' Choice of Seats in 3-3-3 Abreast Cabins Such as Boeing 787.

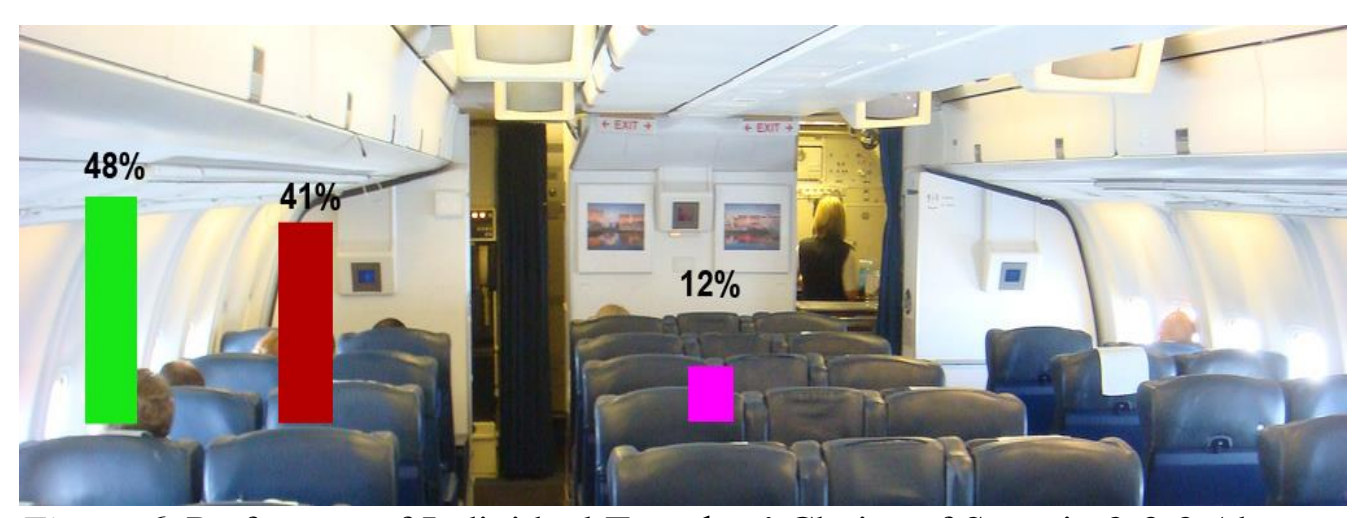

Figure 6. Preference of Individual Travelers' Choice of Seats in 2-3-2 Abreast Cabins Such as Boeing 767.

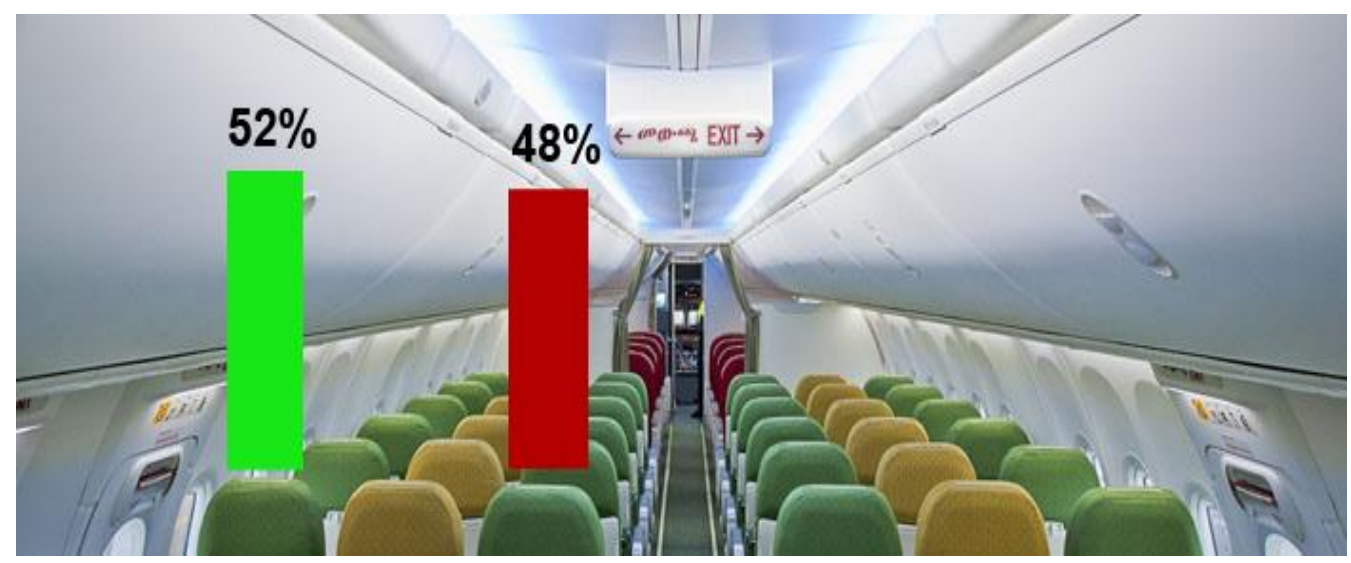

Figure 7. Preference of Individual Travelers' Choice of Seats in 3-3 Abreast Cabins Such as Boeing 757. 


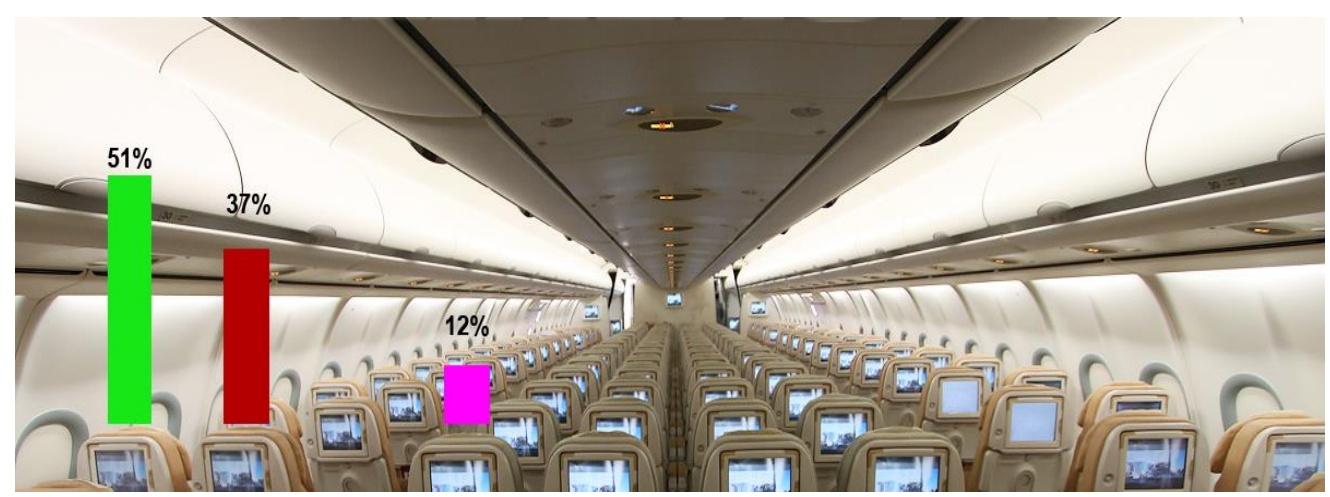

Figure 8. Preference of Individual Travelers' Choice of Seats in 2-4-2 Abreast Cabins such as Airbus A340.

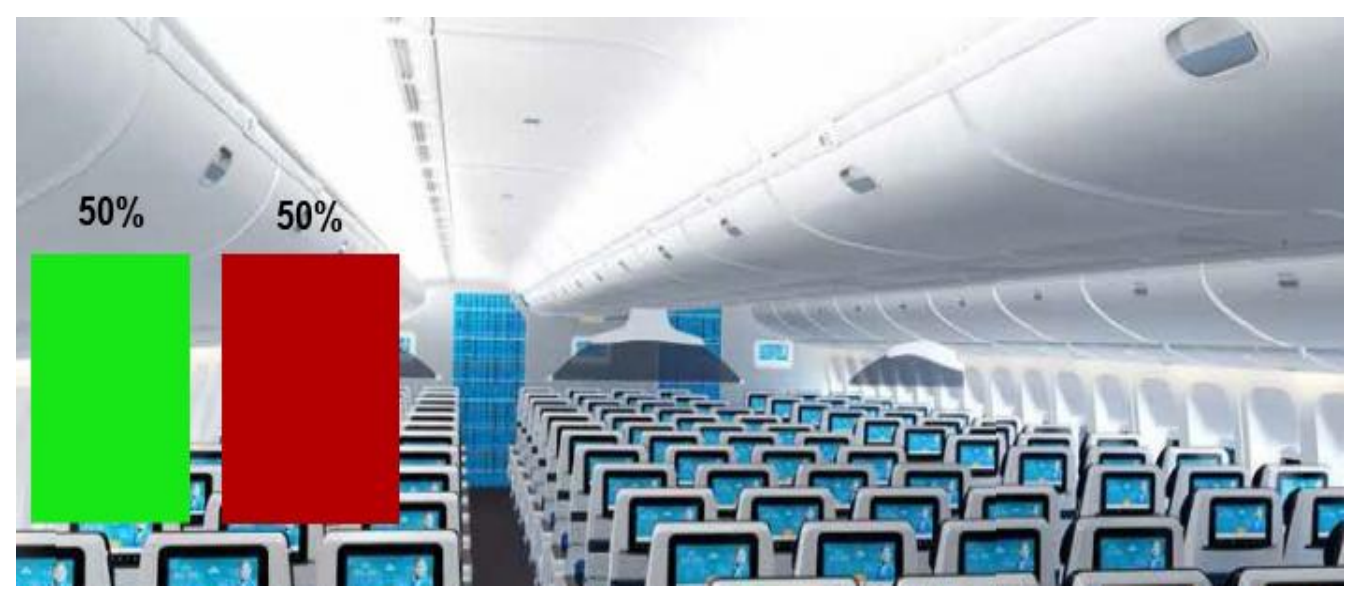

Figure 9. Preference of Couple Travelers' Choice of Seats in 3-4-3 Abreast Cabins Such as Boeing 777.

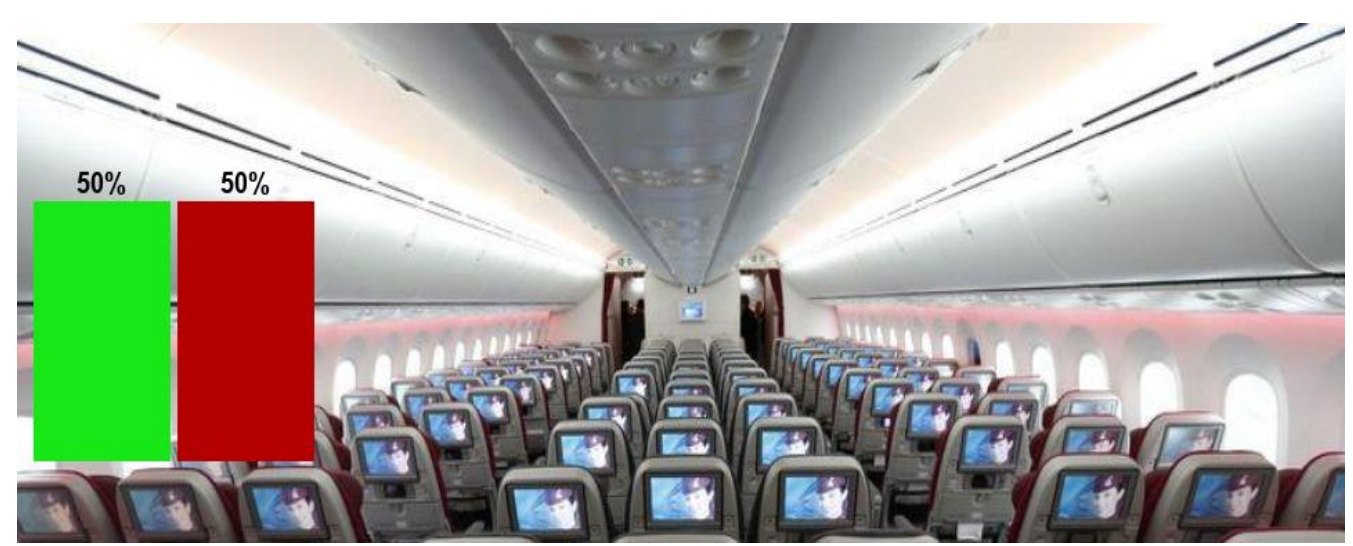

Figure 10. Preference of Couple Travelers' Choice of Seats in 3-3-3 Abreast Cabins Such as Boeing 787. 


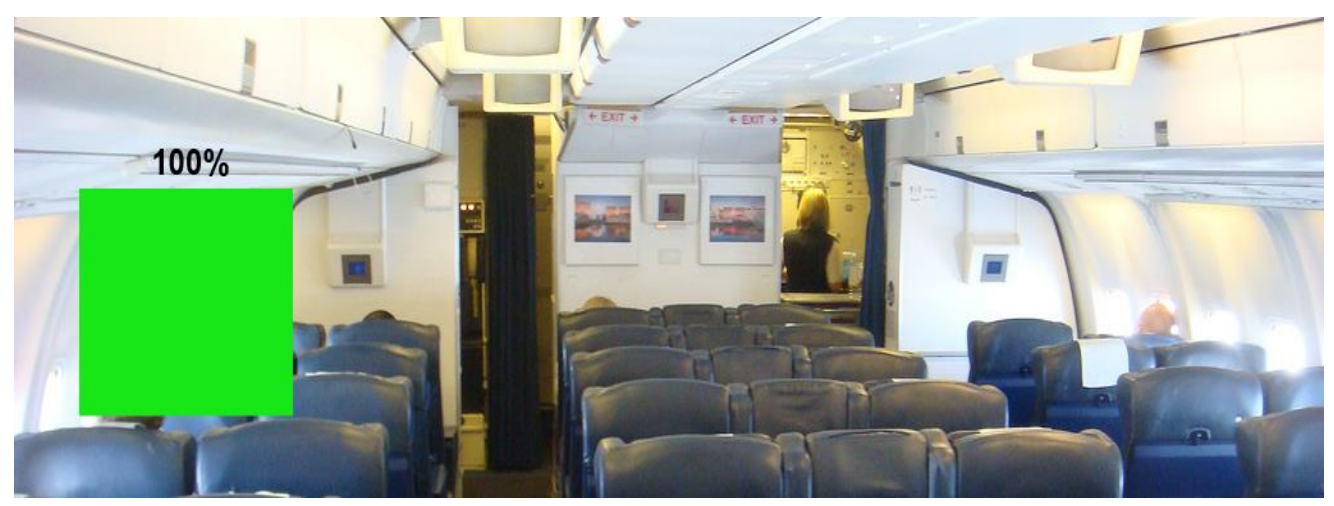

Figure 11. Preference of Couple Travelers' Choice of Seats in 2-3-2 Abreast Cabins Such as Boeing 767.

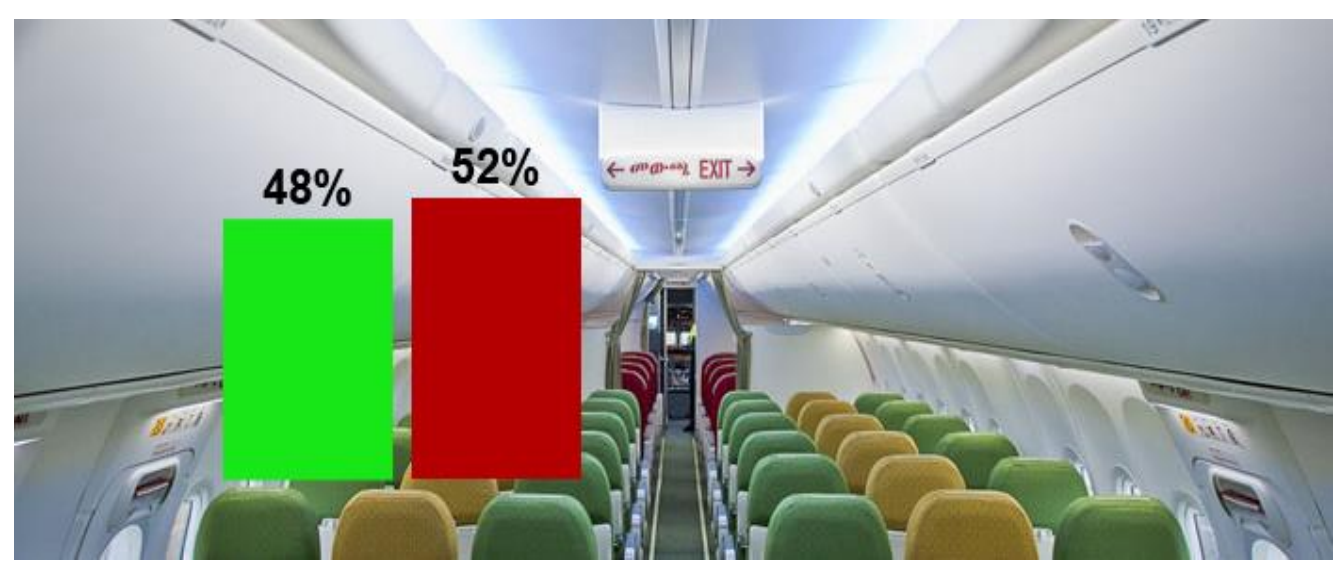

Figure 12. Preference of Couple Travelers' Choice of Seats in 3-3 Abreast Cabins such as Boeing 757.

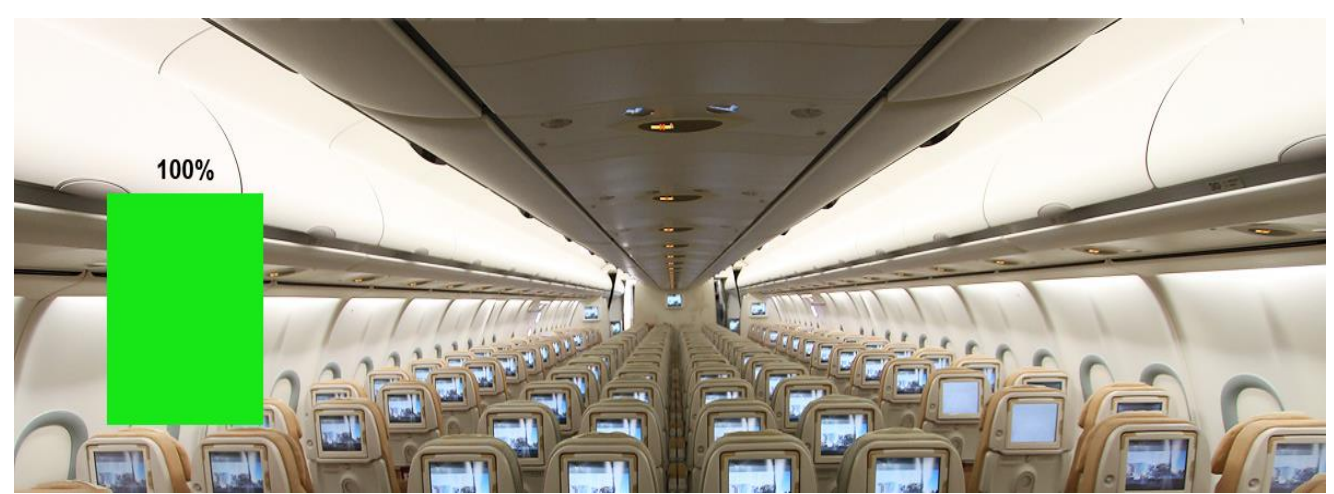

Figure 13. Preference of Couple Travelers' Choice of Seats in 2-4-2 Abreast Cabins Such as Airbus A340. 
Table 1.

The Factors Influencing Flight Choice and Whether This Factor is Significantly Different Using the Zero Hypothesis Test and Tukey Multiple Comparison Test for Factors That Affect Flight Choice Among Individual, Couple, and Group Travelers

\begin{tabular}{|c|c|c|c|c|c|}
\hline \multirow[t]{2}{*}{ row } & \multirow{2}{*}{$\begin{array}{l}\text { Flight choice } \\
\text { affecting } \\
\text { factors }\end{array}$} & \multirow[t]{2}{*}{$\mathrm{P}$ value } & $\begin{array}{l}P \text { adj } \\
\mu 1=\mu 2\end{array}$ & $\begin{array}{l}P \text { adj } \\
\mu 1=\mu 3\end{array}$ & $\begin{array}{l}P \text { adj } \\
\mu 2=\mu 3\end{array}$ \\
\hline & & & $\begin{array}{l}1=\text { Individuals, } \\
2=\text { Couples }\end{array}$ & $\begin{array}{l}\text { 1=Individuals, } \\
3=\text { Groups }\end{array}$ & $\begin{array}{l}2=\text { Couples, } \\
3=\text { Groups }\end{array}$ \\
\hline 1 & $\begin{array}{l}\text { schedule of } \\
\text { time table }\end{array}$ & $\begin{array}{l}0.0378 \\
*\end{array}$ & 0.4938551 & 0.0291397 & 0.2390033 \\
\hline 2 & ticket price & 0.21 & - & - & - \\
\hline 3 & seat comfort & $\begin{array}{l}0.0334 \\
*\end{array}$ & 0.0546112 & 0.9569207 & 0.0824701 \\
\hline 4 & $\begin{array}{l}\text { airlines } \\
\text { image }\end{array}$ & 0.374 & - & - & - \\
\hline 5 & $\begin{array}{l}\text { inflight } \\
\text { service }\end{array}$ & 0.42 & - & - & - \\
\hline 6 & $\begin{array}{l}\text { loyalty } \\
\text { program }\end{array}$ & - & - & - & - \\
\hline 7 & $\begin{array}{l}\text { nonstop } \\
\text { point to point } \\
\text { flight }\end{array}$ & - & - & - & - \\
\hline
\end{tabular}

Table 2.

Comparison of Importance Rate Regarding "Talking to the Neighbors" Among Different Traveler Types

\begin{tabular}{|l|l|l|l|l|l|}
\hline & $\begin{array}{l}\text { Not at all } \\
\text { important }\end{array}$ & $\begin{array}{l}\text { Not very } \\
\text { important }\end{array}$ & $\begin{array}{l}\text { Somewhat } \\
\text { important }\end{array}$ & $\begin{array}{l}\text { Very } \\
\text { important }\end{array}$ & $\begin{array}{l}\text { Extremely } \\
\text { important }\end{array}$ \\
\hline Individuals & $33 \%$ & $38 \%$ & $25 \%$ & $4 \%$ & $0 \%$ \\
\hline Couples & $25 \%$ & $25 \%$ & $35 \%$ & $15 \%$ & $0 \%$ \\
\hline Groups & $27 \%$ & $18 \%$ & $46 \%$ & $9 \%$ & $0 \%$ \\
\hline
\end{tabular}


Table 3.

Comparison of Satisfaction Rate Regarding "Talking to the Neighbors" Among Different Traveler Types

\begin{tabular}{|l|l|l|l|l|l|}
\hline & $\begin{array}{l}\text { Not at all } \\
\text { satisfied }\end{array}$ & $\begin{array}{l}\text { Not very } \\
\text { satisfied }\end{array}$ & $\begin{array}{l}\text { somewhat } \\
\text { satisfied }\end{array}$ & $\begin{array}{l}\text { Very } \\
\text { satisfied }\end{array}$ & $\begin{array}{l}\text { Extremely } \\
\text { satisfied }\end{array}$ \\
\hline Individuals & $21 \%$ & $8 \%$ & $46 \%$ & $21 \%$ & $4 \%$ \\
\hline Couples & $5 \%$ & $15 \%$ & $65 \%$ & $15 \%$ & $0 \%$ \\
\hline Groups & $0 \%$ & $9 \%$ & $64 \%$ & $27 \%$ & $0 \%$ \\
\hline
\end{tabular}

\section{Discussion}

Regarding the research question on the influence of activities in aircraft interior satisfaction, it is clear that most of the travelers prefer to rest/relax, use the bathroom and sleep. This is to some extent similar to other studies. A study of IATA (2015) showed that watching IFE (72\%), sleeping (70\%), and eating/drinking (42\%) were rated as the most important activities during longhaul flights. Groenesteijn et al. (2014) observed activities during train rides and relaxing $(23 \%)$, talking (23\%), reading (19\%), and sleeping (13\%) were most seen. So, sleeping is seen in all studies. Probably in the IATA study relaxing is seen as a part of sleeping, since relaxing is not mentioned in that study. The bathroom is unique for this study but was not specifically addressed in the IATA study and the Groenesteijn study. Related to seat configuration it means that features are needed for relaxing and sleeping, since all types of travelers (individual, couples and groups) consider these activities important.

The satisfaction rate was the highest while watching IFE and thinking/observing. This is mentioned in other studies as well. Lewis et al. (2016) showed that it is possible to distract from discomfort by using IFE. Sleeping and in-/egress had the lowest satisfaction rate, which is demonstrated in other studies as well. Bouwens et al. (2018) showed in a study among high and low peaks in comfort the lowest comfort in cruise flight, and one of the factors was because sleeping is difficult. The difficulty with in- and egress is mentioned in the study of Lijmbach et al. (2014) as well. Talking to the neighbor was also found least satisfactory among all types of passengers in this study which is an interesting finding. Individual travelers considered this activity less important than other travelers (71\%) (Table 2), while they also showed less satisfaction by performing this activity compared to the two other groups of couple and group travelers (21\%) (Table 3$)$.

The seat preference for aisle and window has been described before as well; however not with these exact numbers. Vink \& Brauer (2011) mention that the middle seat is least preferred. In this study the middle seat is only preferred when the group is of three or larger than three persons. The idea of dividing importance and satisfaction rates by different compositions (individual, couples, and groups) was unique in this study. In addition, this study showed that the activity of "taking care of family and kids" is less satisfactory 
for group travelers which shows also the importance of this activity to this specific group as well. This group also show less satisfaction with the activity "interaction with flight attendant" compared to individual and couple travelers. For individuals, this is more important. The study by Chen (2008) showed a similar outcome in a study among 300 long-haul passengers. He identified that the most important factors for a good service are staff and facilities. It explained $19 \%$ of the variance. The study also shows that "schedule of time table" and "seat comfort" are more significant in couples' selection of flight which is significantly different from individual and group travelers.

This study has also some drawbacks. One drawback could be that the rating is influenced by post-flight interpretations. However, Bouwens et al. (2017) showed no significant differences between the scores gathered during flight and after flight. Another drawback of this study could be that we focused on elements that passengers are aware of. Using other methods like context mapping (Sleeswijk-Visser, 2009) other aspects that are important too of which passengers may not be aware can be found. Mellert et al. (2008) for instance showed that noise itself is not noticed, but they found that passengers with swollen feet are more aware of this situation under noisy conditions. This awareness increased by $43 \%$ in the noisier conditions. Another way to make people more aware of aspects of the interior is to take into account different senses (Bouwens et al., 2018) and at aspects including light, smell and noise. However, this will not give direct directions for improving interior design. A third drawback could be that not enough attention is paid to the diverse travelers including their disabilities, physical aspects, cultural aspects etc., while the percentage of diverse travelers will increase due to the fact that there will be more elderly.

To cope with the different passengers needs and to create more satisfaction, it would be interesting to create areas dedicated to activities for special groups, or make the airplane adaptive. Perhaps the idea of Airbus on the modular interior is a solution to this problem.

\section{Conclusion}

This study confirmed previous findings that for instance the middle seat is less popular. On the other hand, additional insights into the perception of long-haul passenger activities and their specific satisfaction related to these activities were gathered.

The main findings of this research are that we should create various passenger spaces for those travelling individually and those travelling in various groups and adapt the interior to activities that passengers like to do the most. This will provide each group with features and facilities that are designed to specifically cover requirements for both groups and individuals. This is a concept called segmentation which focuses on each user profile independently. Indeed, by addressing passenger segments, we could create accordingly customized facilities that will better accommodate their needs, and therefore improve their in-flight experience. 


\section{References}

Alderighi, M., Cento, A., Nijkamp, P., \& Rietveld, P. (2012). Competition in the European aviation market: The entry of low-cost airlines. Journal of Transport Geography, 24, 223-233.

Blok, M., Vink, P., \& Kamp, I. (2007). Comfortable flying: Comfort of the aircraft interior by the end user. Tijdschrift voor Ergonomie, 32(4), 411.

Bouwens, J., Hiemstra-van Mastrigt, S., \& Vink, P. (2018). Ranking of human senses in relation to different in-flight activities contributing to the comfort experience of airplane passengers. International Journal of Aviation, Aeronautics, and Aerospace, 5(2), 9.

Bouwens, J., Tsay, W. J. J., \& Vink, P. (2017). The high and low comfort peaks in passengers' flight. Work, 58(4), 579-584.

Brauer, K. (2004). Convenience, comfort and cost: the Boeing perspective on passenger satisfaction [PowerPoint slides]. In The Aircraft Interior EXPO’04, March 30-April 1, 2004. Hamburg, Germany.

Chen, C. F. (2008). Investigating structural relationships between service quality, perceived value, satisfaction, and behavioural intentions for air passengers: Evidence from Taiwan. Transportation Research Part A: Policy and Practice, 42(4), 709-717.

De Lille, C., Santema, S., Bouwens, J., Schultheis, U., \& Vink, P. (2016). Designing the cabin interior knowing high and low peaks in a passenger flight. AEGATS Conference Paris, abstract $n r$ AEGATS2016_48.

Groenesteijn, L., Hiemstra-van Mastrigt, S., Gallais, C., Blok, M., Kuijt-Evers, L., \& Vink, P. (2014). Activities, postures and comfort perception of train passengers as input for train seat design. Ergonomics, 57(8), 1154-1165.

Harrison, A., Popovic, V., Kraal, B. J., \& Kleinschmidt, T. (2012). Challenges in passenger terminal design: A conceptual model of passenger experience. In Proceedings of the design research society (DRS) 2012 conference (pp. 344-356). Department of Industrial Design, Faculty of Architecture, Chulalongkorn University.

Hiemstra-van Mastrigt, S. (2015). Comfortable passenger seats: Recommendations for design and research (Doctoral dissertation). Delft, Netherlands: Delft University.

Konieczny, G. (2001). Measuring and increasing the quality of aircraft cabin services - a contribution to customer-oriented aircraft development (Doctoral dissertation). Berlin, Germany: Technical University Berlin.

López-Bonilla, J. M., \& López-Bonilla, L. M. (2008). Influence of the stateowned airlines on passenger satisfaction. Journal of Air Transport Management, 14(3), 143-145.

Meinel, C., Leifer, L., \& Plattner, H. (2010). Design thinking: Understandimprove-apply. Zurich, Switzerland, Springer. 
Mellert, V., Baumann, I., Freese, N., \& Weber, R. (2008). Impact of sound and vibration on health, travel comfort and performance of flight attendants and pilots. Aerospace Science and Technology, 12(1), 1825.

Popovic, V., Kraal, B., \& Kirk, P. J. (2010). Towards airport passenger experience models. In Proceedings of 7th International Conference on Design \& Emotion, Chicago, IL.

Sleeswijk-Visser, F. (2009). Bringing the everyday life of people into design. Delft, Netherlands: TU-Delft.

Smulders, M., Berghman, K., Koenraads, M., Kane, J. A., Krishna, K., Carter, T. K., \& Schultheis, U. (2016). Comfort and pressure distribution in a human contour shaped aircraft seat (developed with $3 \mathrm{~d}$ scans of the human body). Work, 54(4), 925-940.

Vink P., \& Brauer, K. (2011). Aircraft interior comfort and design. CRC: Boca Raton, FL.

Vink, P., Bazley, C., Kamp, I., \& Blok, M. (2012). Possibilities to improve the aircraft interior comfort experience. Applied Ergonomics, 43(2), 354359. 